\title{
Short- and long-term effects of nutrient enrichment on microbial exoenzyme activity in mangrove peat
}

\author{
Joost A. Keuskamp ${ }^{\mathrm{a}, *}$, Illka C. Feller ${ }^{\mathrm{b}}$, Hendrikus J. Laanbroek ${ }^{\mathrm{a}, \mathrm{c}}$, Jos T.A. Verhoeven ${ }^{\mathrm{a}}$, Mariet M. \\ Hefting $^{\mathrm{a}}$ \\ ${ }^{a}$ Ecology and Biodiversity, Department of Biology, Utrecht University, Padualaan 8, 3584 CH, Utrecht, The Netherlands \\ ${ }^{b}$ Smithsonian Environmental Research Center, Edgewater, MD 21037, USA \\ ${ }^{c}$ Department of Microbial Wetland Ecology Netherlands Institute of Ecology (NIOO-KNAW), Wageningen, The Netherlands
}

\begin{abstract}
Mangrove forests exhibit intense carbon and nutrient cycling with globally relevant rates of carbon sequestration. In oceanic mangrove systems, carbon deposition in peat layers is essential to avoid inundation due to sea level rise. In many parts of the world, mangroves are being exposed to increasing quantities of external nitrogen due to coastal development, and it is not known how nutrient cycling and carbon sequestration will be affected. We hypothesised that tannins induce a nitrogen limitation on microbial decomposition even when plant growth is limited by phosphorus, creating a situation of differential nutrient limitation between plants and microbial communities. To examine such differential nutrient limitation, we quantified the short- and long-term effects of nitrogen and phosphorus enrichment on microbial biomass and decomposition-related enzyme activities in a Rhizophora mangle -dominated mangrove, which had received fertilisation treatments for fifteen years at the time of this study. We compared microbial biomass, stoichiometry and potential enzyme activity in dwarf and fringe-type $R$. mangle dominated sites, where primary production is limited by phosphorus or nitrogen depending on the proximity to open water.

Even in phosphorus-limited mangroves, microbial activity was nitrogen limited. Such a differential nitrogen-limitation between microbial decomposers and primary producers implies that the impact of nutrient enrichment on carbon sequestration is nutrient-specific. In addition, this paper shows that phenol oxidase activities in this system decreases through $\mathrm{P}$, but not through N-enrichment. Furthermore it is argued that the often used division between N-harvesting, P-harvesting, and C-harvesting exoenzymes needs to be reconsidered.
\end{abstract}

Keywords: Rhizophora, peat, microbial activity, SOC, decomposition, differential nutrient limitation

\section{Introduction}

Mangrove ecosystems are commonly found in tropical and subtropical coastal zones, where they are of major importance to local nutrient and carboncycling (Alongi, 1996). Mangroves typically grow in the subtidal and intertidal zones with their lower range being imposed by the need to have their aerenchymatous roots exposed to the atmosphere

\footnotetext{
* Corresponding author

Email addresses: j.a.keuskamp@uu.nl (Joost A. Keuskamp), feller@serc.si.edu (Illka C. Feller), h.j.laanbroek@nioo.knaw.nl (Hendrikus J. Laanbroek), j.t.a.verhoeven@uu.nl (Jos T.A. Verhoeven), m.m.hefting@uu.nl (Mariet M. Hefting)
}

during low tides (Ball, 1998). Therefore, in the absence of soil elevation, rising sea levels lead to dieback of mangroves. In systems where sediment input is not substantial, survival of mangroves depends mostly on the build-up of peat (McKee, 2011), resulting from the imbalance between primary production and decomposition. Nutrient enrichment in these systems can influence both these processes. Eutrophication, therefore, may have unforeseen effects on mangrove stability (McKee et al., 2007) leading to habitat loss if soil accumulation is negatively affected.

Decomposition is catalyzed by several key exoenzymes that allow for extracellular conversion of complex organic matter into simpler products, 
such as glucose, amino acids, and phosphate. Tannins are known to influence microbial decomposition rates. Mangrove litter, especially from Rhizophora spp, contains large amounts of dissolvable and non-dissolvable tannins (Alongi, 1987; Zhang et al., 2010; Maie et al., 2006). As protein-binding phenolic compounds, tannins inhibit microbial activity and lower nutrient mobilisation via substrate deprivation and enzyme inhibition (Kraus et al., 2003; Schimel et al., 1996; Joanisse et al., 2007). The immobilisation of exoenzymes in tannin-rich soils decreases their activity (Ximenes et al., 2011), resulting in reduced return of degradation products per unit of investment of nitrogen $(\mathrm{N})$, carbon $(\mathrm{C})$, and energy for producing exoenzymes. This induces energy and $\mathrm{N}$ limitation in microorganisms producing these enzymes, thereby suppressing microbial decomposing activity.

We hypothesise that decomposer microorganisms in mangroves are ultimately N-limited, due tanninprotein complexation. If primary production is phosphorus (P)-limited, tannin-induced N limitation for micro-organisms will lead to a differential nutrient limitation (DNL) for plants versus decomposing micro-organisms. DNL would result in nutrient-specific biogenic controls of soil level in mangrove ecosystems. In such a system, enrichment in the plant-limiting nutrient $(\mathrm{P})$ would result in net peat accumulation, whereas enrichment in the microbe-limiting nutrient $(\mathrm{N})$ would result in net peat loss. The latter poses a large threat to mangrove systems on a global scale, because many coastal systems are experiencing increasing $\mathrm{N}$ inputs resulting from anthropogenic activity (Howarth and Marino, 2006).

Earlier studies have attempted to quantify the effects of nutrient enrichment on peat decomposition in mangrove systems, using decomposition rates of roots (McKee et al., 2007) or tensile strength loss of cotton-strips (Feller et al., 2002) as indicators. These studies suggested that decomposition was either P-limited (Feller et al., 2002) or not sensitive to nutrient enrichment (McKee et al., 2007). However, (McKee et al., 2007) observe peat decline upon $\mathrm{N}$ fertilisation which is possibly attributable to increased decomposition rates (Lovelock et al., 2011).

A mechanistic approach that employs the measurement of both hydrolytic and oxidative exoenzymes involved in the breakdown of organic matter provides a means to reconcile these seemingly contradictory results. Microorganisms catalyse the rate-limiting step in nutrient-cycling and decompo- sition of organic matter contained in peat (Sinsabaugh, 1994; Freeman et al., 2004) and their activities correlate with the rate of soil organic $\mathrm{C}$ decay and microbial nutrient demand (Sinsabaugh et al., 2009). Hydrolytic enzymes catalyse specific reactions and are frequently used to determine whether decomposition is limited by $\mathrm{N}$ or $\mathrm{P}$ (Sinsabaugh and Moorhead, 1994). Oxidative enzymes, on the other hand, are much less specific but show strong correlations with decomposition rate of recalcitrant organic compounds in peat (Freeman et al., 2004; Limpens et al., 2008)

To gain insight into the effects of nutrientenrichment on enzyme mediated decomposition processes in mangrove systems, we used two complementary approaches: i) measuring the effects of long-term nutrient fertilisation in field experiments, and ii) tracking the short-term impact of nutrient enrichment in laboratory incubations.

The fertilisation field experiment allows one to examine the long-term, in-situ consequences of nutrient enrichment on enzyme activities in the context of complex interactions between microorganisms and plants competing for nutrients. The shortterm amendments serve to assess the response to nutrient and $\mathrm{C}$ enrichment without the confounding effects of plant-soil interactions. These results can also be used as a benchmark to interpret the responses in enzyme activities to in the long-term fertilisation experiment. In addition to quantifying potential enzyme activities, we compared microbial biomass, elemental stoichiometry, and metabolic activity to test the hypothesis that tannin production induces a $\mathrm{N}$ limitation in decomposing microorganisms regardless of the limitations for primary production

The present study was conducted at Twin Cays, a mangrove-dominated oceanic island group in the Caribbean Sea, $16 \mathrm{~km}$ off the coast of Dangriga, Belize. The islands consist of mangrove-derived peat, which is up to $10 \mathrm{~m}$ thick (McKee et al., 2007). The dominant mangrove species on the island, $R h i$ zophora mangle shows a clear zonation with respect to growth form and nutrient limitation: Trees on the inland parts of the island show stunted growth and are strongly P-limited, while trees are much taller near the fringes of the island, where primary production is not limited by $\mathrm{P}$ (Feller et al., 2002).

Following from our hypothesis, we expected microbial decomposition to be ultimately N-limited in both the dwarf and the fringe zone, so that the dwarf zone has DNL, while the fringe zone has 
not. We expected the short-term response to nutrient amendments to reflect the direct effect of nutrients on enzyme production, which allows revealing any differences with the long-term effects to be attributed to plant-mediated influences such as changes in tannin production and litter quality change. The results from this study can be used to evaluate the use of enzyme activities to assess microbial nutrient limitations, and to qualify the potential consequences of eutrophication with respect to peat decomposition in mangroves.

\section{Materials and Methods}

\subsection{Study Site and field experiment}

Soil and water samples were collected at Twin Cays, Belize $\left(16^{\circ} 49^{\prime} \mathrm{N}, 88^{\circ} 6^{\prime} \mathrm{W}\right)$. An extensive description of the hydrology, climate, primary production, and soil properties can be found in (Feller, 1995; Feller et al., 1999, 2002; McKee et al., 2007; Lee et al., 2008; Feller et al., 2009).

At the moment of sampling, the R. mangle dominated sites had been fertilised with either $\mathrm{N}$ or $\mathrm{P}$ for over 15 years using the method as described in (Feller, 1995). In short, the fertilisation consisted of the biannual burial of two pieces of dialysis tubing filled with $150 \mathrm{~g}$ of either urea for $\mathrm{N}$ fertilisation or triple superphosphate for $\mathrm{P}$ fertilisation at opposing sides close to the base of each fertilised tree.

Feller et al. (2002) gives a detailed explanation of the lay-out of the long-term fertilisation experiment. Transects with a maximum length of $50 \mathrm{~m}$ perpendicular to the coastline were established on three randomly chosen positions (Feller, 1995). At each position, three parallel transects with a lateral distance of about $10 \mathrm{~m}$ were established and a fertilisation treatment (control, $\mathrm{P}$ fertilisation and $\mathrm{N}$ fertilisation was randomly assigned to each of these transects. Each transect comprised of a fringe zone where $R$. mangle trees showed tall $(5-6 \mathrm{~m})$ growth, a narrow transition zone with intermediate tree heights, and a dwarf zone, where $R$. mangle trees showed stunted growth with distinctively lower tree height $(<1.5 \mathrm{~m})$ and density.

Some basic soil properties of dwarf and fringe zones are given in Table 1 . The two zones did not differ significantly with respect to $\mathrm{pH}$ and bulk density, but salinity and temperature were lower in the fringe sites, which had markedly taller trees.

\subsection{Soil level calculations}

At each site, the difference between soil and water level was measured using a ruler, and the time of measurement was denoted. Soil elevation relative to Mean Lower Low Water (MLLW) was calculated using the TideCal 10 (Kaleberg Symbionts, 2010) OS X port of Xtide v 2.10 (Flater, 2008) with the tide_db V1.07 harmonics file (Depner, 2003) using the Belize City measurement station as a reference.

\subsection{Sample collection and processing}

In spring 2012, average tree height and density were measured in a $2 \times 2 \mathrm{~m}$ quadrant with the fertilised tree as the centre. Soil and porewater samples were taken approximately $10 \mathrm{~cm}$ from the base of the tree. Porewater was collected using $10 \mathrm{~cm}$ long rhizons (Eijkelkamp BV, Giesbeek, The Netherlands). Soil samples were taken by extracting cores with a depth of $10 \mathrm{~cm}$ using a stainless steel corer with a diameter of $9.6 \mathrm{~cm}$. All samples taken in the field were transported to the lab within 12 hours and stored at $3{ }^{\circ} \mathrm{C}$ until further processing. After determination of soil bulk density, roots larger than $2 \mathrm{~mm}$ were removed and all samples were homogenised before further processing. Gravimetric soil moisture was determined based on moisture loss upon $48 \mathrm{~h}$ of oven drying at $70^{\circ} \mathrm{C}$. Soil was freezedried and ground at 20 RPM using an MM200 mixer mill (Retsch GmbH, Haan, Germany). Total organic $\mathrm{C}$ and total $\mathrm{N}$ were determined using an EA/110 elemental CN analyser (InterScience BV, Breda, The Netherlands) after washing with a $32 \%$ $\mathrm{HCl}$ solution to remove calcium carbonates.

Tannin content was determined using the FolinCiocalteu reagens for phenolic compounds following the recommendations of Cicco and Lattanzio (2011) to avoid formation of precipitations. Tannins were extracted by shaking $15 \mathrm{mg}$ freeze-dried soil with $2 \mathrm{ml}$ extraction fluid at $40^{\circ} \mathrm{C}$ for $1 \mathrm{~h}$ at 20 rpm, using deionised water as a solvent for soluble tannins and a 50\%-50\% methanol-water mixture as a solvent for total tannin extraction. After determination of concentrations of total and soluble phenolic compounds, the insoluble tannin concentration was calculated as the total concentration minus the soluble phenolic compounds. $\mathrm{PO}_{4}{ }^{3-}, \mathrm{NH}_{4}{ }^{+}, \mathrm{NO}_{3}{ }^{-}$, dissolved organic $\mathrm{N}$, and dissolved organic $\mathrm{C}$ (DOC) measurements of porewater was conducted using a continuous flow auto analyser (Skalar SA-40, Breda, The Netherlands). 


\subsection{Microbial biomass and stoichiometry}

Microbial biomass and stoichiometry was determined using a fumigation-extraction procedure as also described in (?). After extraction with a $0.5 \mathrm{M}$ $\mathrm{K}_{2} \mathrm{SO}_{4}$ solution, we measured the amount of extracted $\mathrm{N}, \mathrm{P}$ and $\mathrm{C}$ compounds that were liberated by a $24 \mathrm{~h}$ fumigation with ethanol-free chloroform. To estimate microbial content of $\mathrm{C}, \mathrm{N}$, and $\mathrm{P}$ we divided the liberated amounts of these substances by their respective extractable fractions: 0.38 for C (Vance et al., 1987), 0.54 for N (Brookes et al., 1985) and 0.4 for $\mathrm{P}$ (Brookes et al., 1982).

\subsection{Short-term incubation experiment}

Following ?, soil cores from non-fertilised dwarf sites were incubated for 7 days at $20^{\circ} \mathrm{C}$ following amendment with all possible combinations of labile organic $\mathrm{C}$ (as glucose), $\mathrm{N}$ (as $\mathrm{NH}_{4} \mathrm{Cl}$ ), and $\mathrm{P}\left(\right.$ as $\mathrm{Na}_{3} \mathrm{HPO}_{4}$ ) leading to a total of eight different treatments. The amount of carbon added was $5 \mathrm{nmol} \mathrm{g}^{-1}$ of fresh soil with molar C:N:P concentrations 50:10:1 as to mimic microbial cellular stoichiometry (Fagerbakke et al., 1996).

\subsection{Potential enzyme activities}

Potential enzyme activity assays of six hydrolytic and two oxidative enzymes were conducted on fresh soil from the various treatments in the dwarf and fringe zones. In addition, potential activities of hydrolytic enzymes were measured in soil from the non-fertilised treatment in the dwarf zone after $96 \mathrm{~h}$ of laboratory incubation with various nutrient amendments. Following (Sinsabaugh et al., 2009, 2008), the measured hydrolytic enzymes can be grouped by their function in acquiring $\mathrm{P}, \mathrm{N}$, or $\mathrm{C}$ and energy. Alkaline (Acid) phosphatase (AP) liberates phosphate through the breakdown of organic phosphate compounds. Leucine aminopeptidase (LAP) and glycine aminopeptidase (GAP) are involved in the acquisition of $\mathrm{N}$-containing compounds. LAP catalyses the hydrolysis of leucine residues from peptides and proteins and GAP preferentially hydrolyses the terminal N-bond of glycine and alanine. Cellobiohydrolase $(\mathrm{CBH})$ and $\beta$-1,4-glucosidase (BG) are subsequently involved in the depolymerisation of cellulose, resulting in free glucose for use as a carbon and energy source. $\beta$-N-acetylglucosaminidase (NAG) cleaves $\mathrm{N}$-acetylglucosamine from the fungal and bacterial cell wall components chitin and murein liberating both $\mathrm{C}$ and $\mathrm{N}$. The oxidative enzymes exam- ined, potential phenol oxidase (POX) and peroxidase (POD), are non-specific and attack $\mathrm{C}$ bonds in complex structures such as tannins and lignin.

Potential enzyme activities were measured based on absorbance measurements in 96-well micro plates, following a protocol modified from (Allison and Vitousek, 2004). An enzyme-specific substrate is added to a soil extract to create substrate saturating conditions. In the enzymic reaction pNP (in case of acid phosphatase, cellobiohydrolase, -glucosidase and -N-acetylglucosaminidase) or pNA (in case of glycine aminopeptidase and leucine aminopeptidase) is formed or L-Dopa (in case of polyphenol oxidase and peroxidase) is broken down. Soil extracts were prepared by suspending $2 \mathrm{~g}$ soil in $20 \mathrm{ml}$ TRIS buffered MBL artificial seawater (Cavanaugh, 1956). To measure enzyme activity, eight wells were filled with $150 \mu \mathrm{l}$ of the suspension and $50 \mu \mathrm{l}$ of TRIS-MBL with or without substrate to serve as reaction and reference wells, respectively. The plates were incubated in the dark at $20^{\circ} \mathrm{C}$ for durations ranging from $30 \mathrm{~min}$ to $3 \mathrm{~h}$, depending on the enzyme of which the activity was assayed. During the incubation, the plates were shaken at 600 RPM to keep soil particles in suspension. After incubation, soils were allowed to precipitate and $100 \mathrm{\mu l}$ of particle-free solution was transferred to a new plate for measurement of the absorption at $405 \mathrm{~nm}$ for pNP- and pNA-containing substrates and at $450 \mathrm{~nm}$ for L-Dopa. Absorbance was measured using a SPECTROstar nano photospectrometer (BMG LABTECH, Offenburg, Germany). Product formation was calculated using the difference in absorbance between reaction and reference wells, corrected for change of absorbance through substrate consumption:

$$
\Delta[P]=\frac{(\Delta A B S)-\alpha_{s}[S]_{t 0}}{\alpha_{p}-\alpha_{s}}
$$

with $\alpha_{s}$ and $\alpha_{p}$ absorption coefficients of enzyme substrate and product respectively. $\triangle A B S$ was calculated as the difference of the median absorbances measured in the reaction and the reference well. Finally, potential enzyme activity was expressed as $\Delta P$ g soil $\mathrm{DW}^{-1} \mathrm{~h}^{-1}$.

\subsection{Data analysis 8 Statistics}

Results were analysed using R (R Core Team, 2012) and the $\mathrm{R}$ packages nlme (Pinheiro et al., 2012) for linear-mixed effect modeling and car (?) for type II sum of squares. Treatment effects on 
porewater nutrient concentrations were tested using the non-parametric Wilcoxon Rank Sum test due to the strong heteroscedacity. The other data were fitted to linear mixed-effects models with nutrient treatment or zone as fixed factor with transect and sampling location as random factors where appropriate. Homoscedasticity was confirmed by Levene's test and normality was checked using Shapiro's test. In the enzyme analysis, outliers were identified as being more than two times the interquartile range from the first or the third quartiles resulting in the removal of $2 \%$ of data points. Treatment effects for random models were tested using Walds $\chi^{2}$ test with type II sum of squares.

\section{Results}

\subsection{Soil and mangrove characteristics}

Fringe and dwarf zones differed with respect to porewater nutrient and DOC concentrations (Table 2 ): In the dwarf zone, DOC and $\mathrm{NH}_{4}{ }^{+}$concentrations were higher than in the fringe zone, while the fringe zone contained more $\mathrm{PO}_{4}{ }^{3-}$. Soil organic nitrogen (SON) content was slightly lower in the fringe zone, while soil organic carbon (SOC) content, did not differ between the two zones.

At the time of sampling, nutrient levels in the porewater clearly reflected the fertilisation treatments in the dwarf zone, while this was much less so in the fringe zone (Table 2). The $\mathrm{N}$ fertilisation led to a higher $\mathrm{NH}_{4}{ }^{+}$porewater concentration the dwarf, but not in the fringe zone. The $\mathrm{P}$ fertilisation increased porewater $\mathrm{PO}_{4}{ }^{3-}$ concentrations in both zones, but this increase was six times higher in the dwarf zone as compared to the fringe zone.

Phosphorus fertilisation significantly increased tree height in the dwarf, but not in the fringe sites, while $\mathrm{N}$ fertilisation did not affect tree height in either of the zones (Fig. 1a, Table 3). The same was true for relative surface level, which in the dwarf zone was $11 \mathrm{~cm}$ higher in the $\mathrm{P}$ treatment as compared to the control (Fig. 1b, Table 3) and for concentrations of soluble phenolic compounds, which were also higher in the P-fertilised dwarf plots (Fig. 1c, Table 3). Insoluble phenolic compounds showed a different pattern: P-fertilised sites had higher concentrations of insoluble phenolic compounds in both the dwarf and fringe sites as compared to the control treatment, but there was again no effect of $\mathrm{N}$ fertilisation (Fig. 1d, Table 3).

\subsection{Soil microbial characteristics}

Field fertilisation modified both microbial biomass as well as their elemental stoichiometry (Fig. 2, Table 3). In the control, microbial biomass was much lower in the dwarf zone as compared to the fringe zone. Also, the relative $\mathrm{C}$ content of microbial biomass, was low in the dwarf zone as reflected in the lower $\mathrm{C}: \mathrm{N}$ and $\mathrm{C}: \mathrm{P}$ ratios. Microbial $\mathrm{N}: \mathrm{P}$ did not differ between the two zones. Compared to the average ratios for marine microbial biomass as given by (Fagerbakke et al., 1996), the relative $\mathrm{N}$ content was low in both zones, while the relative content of $\mathrm{C}$ is somewhat below average for the dwarf, and above average for the fringe zones.

In the dwarf zone, $\mathrm{N}$ fertilisation decreased microbial biomass, C:N , and C:P , while N:P remained unaffected. $\mathrm{P}$ fertilisation quintupled microbial biomass, while it increased C:N marginally. $\mathrm{C}: \mathrm{P}$ and $\mathrm{N}: \mathrm{P}$ were not significantly different from the control treatment.

Within the fringe zone, $\mathrm{N}$ and $\mathrm{P}$ fertilisation had similar effects such that microbial biomass was lower in both the $\mathrm{N}$ and the $\mathrm{P}$ treatments. Mean $\mathrm{C}: \mathrm{N}$ was not significantly different between control and treatments, while $\mathrm{C}: \mathrm{P}$ was significantly depressed in both the $\mathrm{N}$ as well as the $\mathrm{P}$ treatments. In both zones, microbial N:P remained unaffected by either fertilisation treatment.

\subsection{Enzyme activities in the field}

Potential activities of hydrolytic enzymes involved in $\mathrm{N}, \mathrm{P}$, and $\mathrm{C}$ acquisition as well as potential activities of the oxidative POX enzyme were measured in fresh soil collected from both the fringe and the dwarf zone (Fig. $3 \&$ Table 4). Between dwarf and fringe plots only the potential AP activity differed significantly, with a somewhat higher activity in the control dwarf plot. N-fertilisation led to a higher potential AP activity in the fringe, but not in the dwarf zone. P-fertilisation caused an increased potential GAP and a decreased potential POX activity in both the dwarf and the fringe zone, while it increased potential activities of $\mathrm{CBH}$ and LAP in the fringe zone only. No POD activities are shown, because no POD activity was detectable in either of the sites.

\subsection{Enzyme activities in the short-term incubation experiment}

Responses of potential enzyme activities to shortterm, nutrient amendments in laboratory incubations of dwarf control soils were generally much 
stronger than those observed for long-term nutrient fertilisation in the field (Fig. 4, Table 5). Glucose amendment increased potential activities of BG, LAP, and AP. Without glucose, N amendment had the strongest effect with significant increases in potential BG, LAP and AP activities as compared to the control while $\mathrm{P}$ amendment only increased potential LAP activity. Within the glucose treatment, potential BG, NAG, LAP and AP activities were stimulated by $\mathrm{N}$ addition. The amendment of $\mathrm{P}$ stimulated potential BG activity while it decreased potential AP activity. Both with and without glucose amendment there was a negative interaction effect between $\mathrm{P}$ and $\mathrm{N}$ for potential activities of LAP and AP, because simultaneous amendment led to lower potential activities of these enzymes as compared to $\mathrm{N}$ amendments only.

$\mathrm{CBH}$ and GAP were not significantly affected by any of the nutrient treatments. This result is in contrast to the observed responses to $\mathrm{P}$ enrichment in the long-term fertilisation experiment in the dwarf zone. Conversely, the high sensitivity of AP to short-term $\mathrm{N}$ and glucose enrichment is contrary to the relatively weak responses observed in the long-term treatments.

\section{Discussion}

\subsection{Stoichiometry}

We hypothesised that decomposer microorganisms were N-limited in Twin Cays, even in the dwarf zone where plant growth is P-limited. The elemental stoichiometry of the microbial community in the field supports this hypothesis. Without fertilisation, microbial N:P ratios were below average, and $\mathrm{C}: \mathrm{N}$ ratios were three to four times above the average for aquatic microorganisms (Fagerbakke et al., 1996; Cleveland and Liptzin, 2007). In the dwarf zone, $\mathrm{N}$ fertilisation restored the $\mathrm{C}: \mathrm{N}$ ratios to average global values, but the low N:P ratios even decreased. This indicates that microorganisms were able to accumulate substantial amounts of $\mathrm{P}$, even in the sites where $\mathrm{P}$ is strongly limiting primary production.

Nevertheless, P enrichment quintupled microbial biomass in the dwarf zone, while $\mathrm{N}$ amendment did not have an effect. This is seemingly contradictory to the stoichiometric response to fertilisation. This either means that the soil microbial community is P-limited, like the primary producers, or that microbial growth is somehow indirectly stimulated by higher primary production. Available evidence suggests the latter. In the dwarf zone, $\mathrm{P}$ fertilisation increased primary production (Feller et al., 2002) and $\mathrm{C}$ input to the soil (McKee et al., 2007). At the same time, the microbial $\mathrm{C}: \mathrm{P}$ ratio increased in these plots. In other words, relative microbial $\mathrm{P}$ concentrations decreased despite increased availability of $\mathrm{P}$. The observed increase in microbial biomass upon P-enrichment in the dwarf zone thus appears to be the result of increased $\mathrm{C}$ input, rather than increased $\mathrm{P}$ availability.

\subsection{Enzyme activities in incubation experiments}

Enzyme activity responses to amendments of nutrients and carbon were measured in short-term laboratory incubations, to isolate the direct responses of soil matrix enrichment from plant-mediated responses. Two types of responses were observed in the incubation experiment: i) A change in overall exoenzyme activity, without an apparent shift in relative enzyme activities. We will interpret this as increased overall enzyme production, as a consequence of alleviation of a general limitation to microbial activity; ii) A change in relative enzyme activity. Relative activities of C- and nutrientacquiring exoenzymes are often applied as an indicator for the nature of the nutrient limitations of decomposer micro-organisms, under the assumption that microbial communities optimise their allocation of resources to maximise their productivity (Sinsabaugh and Moorhead, 1994; Sinsabaugh et al., 2010; Sinsabaugh, 1994).

Single amendments of N, P, and labile organic C all rendered similar increases in overall hydrolytic enzyme activity, without markedly changing the relative activities (Figure 4, upper half). From this we conclude that the micro-organisms producing these exo-enzymes are co-limited by each of those elements. This result confirms the observation that Liebig's law of the minimum does not apply to microbial decomposers (Kaspari et al., 2007) possibly resulting from the large amount of simultaneously active species (Danger et al., 2008). Amendment of either $\mathrm{N}$ or $\mathrm{P}$ did not have an effect, but if $\mathrm{C}$ was added concurrently, their effect was super-additive (i.e. with a positive interaction). From this we conclude that labile organic $\mathrm{C}$ was the most limiting for exo-enzyme production. Within the C-amended treatments, the effect of $\mathrm{N}$ on enzyme activity was considerably larger than the effect of $\mathrm{P}$. This confirms the finding from stoichiometry that $\mathrm{N}$ is more limiting to microbial activity than $\mathrm{P}$. 
Stimulation of specific exoenzymes in response to short-term amendments was also observed, although not all responses were easy to interpret. Upon $\mathrm{N}$ amendment, potential activity of the $\mathrm{P}$ acquiring $\mathrm{AP}$ enzyme increased, which matches the expectations based on optimal resource allocation. Activity of the N-harvesting LAP enzyme could however not be explained from this principle as its activity increased with all amendments, including that of N. Similarly, potential NAG activity increased upon $\mathrm{N}$ addition if also glucose was given. Although generally considered as strictly N-harvesting (Sinsabaugh et al., 2009), their end products, leucine $\left(\mathrm{C}_{6} \mathrm{H}_{13} \mathrm{NO}_{2}\right)$ and $\mathrm{N}$ acetylglucosamine $\left(\mathrm{C}_{8} \mathrm{H}_{15} \mathrm{NO}_{6}\right)$ respectively, contain considerably more $\mathrm{C}$ than $\mathrm{N}$. This means that their activity contributes more to energy and $\mathrm{C}$ uptake than to $\mathrm{N}$ uptake, which may explain the unexpected increase in activity even if enough mineral $\mathrm{N}$ is available. The same is true for the end product of GAP (galanine $-\mathrm{C}_{2} \mathrm{H}_{5} \mathrm{NO}_{2}$ )), but in our study, its activity did not respond to any of the given amendments.

\subsection{Enzyme activity in the field fertilisation exper- iment}

In the field fertilisation experiment, responses of enzyme activities to nutrient amendments were much weaker as compared to the laboratory incubations, but they roughly followed the same direction. In contrast to the short-term response, potential LAP, BG and NAG activities were not significantly stimulated by $\mathrm{N}$ amendment. The increased potential activities of AP in the $\mathrm{N}$ fertilised dwarf and fringe zones indicate that $\mathrm{P}$ became the limiting nutrient, while it was not before. Conversely, $\mathrm{P}$ fertilisation increased the potential activity of $\mathrm{N}$ acquiring enzymes LAP and GAP, indicating that N had become limiting, where it was not before. The latter is not in accordance with the elemental stoichiometry of the microbial biomass, which suggests that $\mathrm{N}$ is also limiting in the control. Similar to the short-term incubations, the largest increase in activity of nitrogen acquiring enzymes is observed in LAP. This strengthens the suspicion that that this enzyme is less specific than previously thought, but could also result from a deepening of nitrogen depletion in the rhizosphere resulting from increased plant production. The potential activity of the oxidative POX enzyme decreased after $\mathrm{P}$ fertilisation, while $\mathrm{N}$ did not have an effect. This is in contrast to other studies, which report a decline of POX activity upon N amendment (Saiya-Cork et al., 2002; DeForest et al., 2004; Carreiro et al., 2000) and a neutral effect of $\mathrm{P}$ amendment (Wright and Reddy, 2001).

Despite of the substantially higher microbial biomass in the $\mathrm{P}$ fertilisation treatment of the dwarf zone, the potential enzyme activities did not increase, indicating that the enzyme production per unit microbial biomass decreased in these treatments. This is consistent with the hypothesis that tannins specifically inhibit micro-organisms capable of producing-exoenzymes. $\mathrm{P}$ enrichment consistently decreased POX activity and therefore inhibits decomposition of recalcitrant organic matter. Thus, as an indirect effect of $\mathrm{P}$ amendment, microbial production and turnover of freshly produced labile carbon compounds increased, as indicated by higher microbial biomass. This higher $\mathrm{C}$ turnover and higher microbial biomass did not lead to a positive priming effect on the breakdown of recalcitrant organic matter, as shown by the similar potential activities of hydrolytic enzymes and the lower POX activity in comparison to the non-fertilised sites.

\subsection{Conclusions}

Since long, potential exoenzyme activities have been used to predict microbial decomposer nutrient limitation (Sinsabaugh et al., 1993). We showed that in mangroves, responses of potential exoenzyme activities upon short-term nutrient amendment proved to be similar to long term responses. Short term incubations are therefore a useful tool to predict microbial enzymic responses, without the confounding effects of plant responses to nutrient enrichment. Not all responses in exoenzyme activities could however be directly linked to microbial nutrient limitation, however. The end products of the N-harvesting enzymes GAP, LAP and NAG do not only contain $\mathrm{N}$ but also significant amounts of $\mathrm{C}$ and could therefore well serve as sources of $\mathrm{C}$ and energy. A similar finding was done by Steenbergh et al. (2011) for the 'P-harvesting' enzyme AP, which was shown to relieve microbial carbon limitation in a marine soil. The presumed distinction in 'P-harvesting', N-harvesting' and C-harvesting' enzymes is therefore not as clear-cut as often suggested (in e.g. Sinsabaugh et al. (2009)) and needs to be reconsidered.

The microbial stoichiometry was consistent with the hypothesised $\mathrm{N}$ limitation in the mangrove soils studied. The expected increase in peat decay has 
not been confirmed, as enzyme production is above all C-limited. Overall, the effects of $\mathrm{P}$ enrichment were much larger than that of $\mathrm{N}$, despite the fact that microbial decomposers are $\mathrm{N}$ - limited. In the P-limited dwarf site, $\mathrm{P}$ increased the turnover of labile $\mathrm{C}$ compounds, as indicated by the threefold increase in microbial biomass but decreased the turnover of recalcitrant compounds as indicated by the lower POX activity. This result has been reported for inorganic N (e.g. Hobbie et al. (2012); Sinsabaugh (2010)), but not for P enrichment. As most terrestrial ecosystems are N-limited, it is well possible that the effects found are not specific to the element $\mathrm{N}$ or $\mathrm{P}$ but rather to the element limiting primary production. Whether this is the case, requires more explicit comparison of results from nutrient enrichment in $\mathrm{P}$ - versus $\mathrm{N}$ - limited systems.

\section{Acknowledgements}

We would like to thank Gregg and Joanne Dramer and especially Annemieke Reijngoud for their great help during collection and transport of the field samples collected at Twin Cays, Stefan Jongste, Esther Moens and Karlijn Brouns (UU-LE) for their extensive lab work on the collected samples, George Kowalchuk and Bas Dingemans (UU-LE) for their valuable comments on the manuscript.

This publication was supported by SchureBeijerinck-Popping Fonds (SBP/JK/2010-30) and the Smithsonian Marine Science Network.

\section{References}

Allison, S. D., Vitousek, P. M., 2004. Extracellular enzyme activities and carbon chemistry as drivers of tropical plant litter decomposition. Biotropica 36 (3), 285-296.

Alongi, D. M., Mar. 1987. The influence of mangrove-derived tannins on intertidal meiobenthos in tropical estuaries. Oecologia 71 (4), 537-540.

Alongi, D. M., 1996. The dynamics of benthic nutrient pools and fluxes in tropical mangrove forests. Journal of Marine Research 54, 123-148.

Ball, M. C., 1998. Ecophysiology of mangroves. Trees 2, 129142.

Brookes, P. C., Landman, A., Pruden, G., Jenkinson, D. S., 1985. Chloroform fumigation and the release of soil nitrogen: A rapid direct extraction method to measure microbial biomass nitrogen in soil. Soil Biology and Biochemistry 17 (6), 837-842.

Brookes, P. C., Powlson, D. S., Jenkinson, D. S., 1982. Measurement of microbial biomass phosphorus in soil. Soil Biology and Biochemistry 14 (4), 319-329.
Carreiro, M. M., Sinsabaugh, R. L., Repert, D. A., Parkhurst, D. F., 2000. Microbial enzyme shifts explain litter decay responses to simulated nitrogen deposition. Ecology.

Cavanaugh, G. M. (Ed.), 1956. Formulae and Methods IV of the Biological Laboratory Chemical Room. the Marine Biological Laboratory, Woods Hole, Massachusetts.

Cicco, N., Lattanzio, V., 2011. The Influence of Initial Carbonate Concentration on the Folin-Ciocalteu MicroMethod for the Determination of Phenolics with Low Concentration in the Presence of Methanol: A Comparative Study of Real-Time Monitored Reactions . AJAC 02 (07), $832-839$.

Cleveland, C. C., Liptzin, D., Jul. 2007. C:N:P stoichiometry in soil: is there a "Redfield ratio" for the microbial biomass? Biogeochemistry 85 (3), 235-252.

Danger, M., Daufresne, T., Lucas, F., Pissard, S., Lacroix, G., Oct. 2008. Does Liebig's law of the minimum scale up from species to communities? Oikos 117 (11), 1741-1751.

DeForest, J. L., Zak, D. R., Pregitzer, K. S., Burton, A. J., 2004. Atmospheric Nitrate Deposition, Microbial Community Composition, and Enzyme Activity in Northern Hardwood Forests. Soil Science Society of America Journal 68 (1), 132-138.

Depner, J. C., Jun. 2003. Format for the Oceanographic and Atmospheric Master Library (OAML) Tide Constituent Database. U.S.Naval Oceanographic Office.

Fagerbakke, K. M., Heldal, M., Norland, S., 1996. Content of carbon, nitrogen, oxygen, sulfur and phosphorus in native aquatic and cultured bacteria. Aquatic Microbial Ecology $10,15-27$.

Feller, I. C., 1995. Effects of nutrient enrichment on growth and herbivory of dwarf red mangrove (Rhizophora mangle). Ecological Monographs 65 (4), 477-505.

Feller, I. C., Lovelock, C. E., Piou, C., 2009. Growth and nutrient conservation in Rhizophora mangle in response to fertilization along latitudinal and tidal gradients. Smithsonian Contributions to ....

Feller, I. C., McKee, K. L., Whigham, D. F., O'Neill, J. P., 2002. Nitrogen vs. phosphorus limitation across an ecotonal gradient in a mangrove forest. Biogeochemistry 62 , $145-175$

Feller, I. C., Whigham, D. F., O'Neill, J. P., McKee, K. L., 1999. Effects of nutrient enrichment on within-stand cycling in a mangrove forest. Ecology 80 (7), 2193-2205.

Flater, D., Feb. 2008. XTide version 2.10.

Freeman, C., Ostle, N. J., Fenner, N., Kang, H., 2004. A regulatory role for phenol oxidase during decomposition in peatlands. Soil Biology and Biochemistry 36 (10), 16631667.

Hobbie, S. E., Eddy, W. C., Buyarski, C. R., Carol Adair, E., Ogdahl, M. L., Weisenhorn, P., 2012. Response of decomposing litter and its microbial community to multiple forms of nitrogen enrichment. Ecological Monographs 82 (3), 389-405.

Howarth, R. W., Marino, R., Jan. 2006. Nitrogen as the Limiting Nutrient for Eutrophication in Coastal Marine Ecosystems: Evolving Views over Three Decades. Limnology and Oceanography 51 (1), 364-376.

Joanisse, G. D., Bradley, R. L., Preston, C., Munson, A. D., Jan. 2007. Soil Enzyme Inhibition by Condensed Litter Tannins May Drive Ecosystem Structure and Processes: The Case of Kalmia angustifolia. New Phytologist 175 (3), 535-546.

Kaleberg Symbionts, Oct. 2010. Tidecal- Xtide port for OS 
X. Kaleberg Symbionts.

Kaspari, M., Garcia, M. N., Harms, K. E., Santana, M. Wright, S. J., Yavitt, J. B., Nov. 2007. Multiple nutrients limit litterfall and decomposition in a tropical forest. Ecology Letters 0 (0), 071117033013004-???

Kraus, T. E. C., Dahlgren, R. A., Zasoski, R. J., Oct. 2003. Tannins in nutrient dynamics of forest ecosystems - a review. Plant and Soil 256 (1), 41-66.

Lee, R. Y., Porubsky, W. P., Feller, I. C., McKee, K. L., Joye, S. B., 2008. Porewater biogeochemistry and soil metabolism in dwarf red mangrove habitats (Twin Cays, Belize). Biogeochemistry 87 (2), 181-198.

Limpens, J., Berendse, F., Blodau, C., Canadell, J. G., Freeman, C., Holden, J., Roulet, N., Rydin, H., SchaepmanStrub, G., May 2008. Peatlands and the carbon cycle: From local processes to global implications - A synthesis. Biogeosciences Discussions 5 (2), 1379-1419.

Lovelock, C. E., Ruess, R. W., Feller, I. C., 2011. Co 2 efflux from cleared mangrove peat. PLoS ONE 6 (6).

Maie, N., Jaffé, R., Miyoshi, T., Childers, D. L., May 2006. Quantitative and Qualitative Aspects of Dissolved Organic Carbon Leached from Senescent Plants in an Oligotrophic Wetland. Biogeochemistry 78 (3), 285-314.

McKee, K. L., Mar. 2011. Biophysical controls on accretion and elevation change in Caribbean mangrove ecosystems. Estuarine, Coastal and Shelf Science 91 (4), 475-483.

McKee, K. L., Cahoon, D. R., Feller, I. C., 2007. Caribbean mangroves adjust to rising sea level through biotic controls on change in soil elevation. Global Ecology and Biogeography 16 (5), 545-556.

Pinheiro, J., Bates, D., DebRoy, S., Sarkar, D., R Core Team, Jan. 2012. nlme: Linear and Nonlinear Mixed Effects Models. 3rd Edition.

R Core Team, 2012. R: A language and environment for statistical computing.

Saiya-Cork, K. R., Sinsabaugh, R. L., Zak, D. R., Sep. 2002. The effects of long term nitrogen deposition on extracellular enzyme activity in an Acer saccharum forest soil. Soil Biology and Biochemistry 34 (9), 1309-1315.

Schimel, J. P., Van Cleve, K., Cates, R. G., Clausen, T. P., Reichardt, P. B., 1996. Effects of balsam poplar (Populus balsamifera) tannins and low molecular weight phenolics on microbial activity in taiga floodplain soil: Implications for changes in $\mathrm{N}$ cycling during succession. Canadian Journal of Botany 74 (1), 84-90.

Sinsabaugh, R. L., Jan. 1994. Enzymic analysis of microbial pattern and process. Biology and Fertility of Soils 17 (1), 69-74.

Sinsabaugh, R. L., Mar. 2010. Soil Biology \& Biochemistry. Knowledge gaps in soil $\mathrm{C}$ and $\mathrm{N}$ interactions 42 (3), 391404.

Sinsabaugh, R. L., Antibus, R. K., Linkins, A. E., 1993. Wood decomposition: nitrogen and phosphorus dynamics in relation to extracellular enzyme activity. Ecology.

Sinsabaugh, R. L., Hill, B. H., Shah, J. J. F., Oct. 2009. Ecoenzymatic stoichiometry of microbial organic nutrient acquisition in soil and sediment. Nature 462 (7274), 795798.

Sinsabaugh, R. L., Horn, D. J., Follstad Shah, J. J., Findlay, S., Jun. 2010. Ecoenzymatic Stoichiometry in Relation to Productivity for Freshwater Biofilm and Plankton Communities. Microbial Ecology 60 (4), 885-893.

Sinsabaugh, R. L., Lauber, C. L., Weintraub, M. N., Ahmed, B., Allison, S. D., Crenshaw, C., Contosta, A. R., Cusack, D., Frey, S., Gallo, M. E., Gartner, T. B., Hobbie, S. E.,
Holland, K., Keeler, B. L., Powers, J. S., Stursova, M., Takacs-Vesbach, C., Waldrop, M. P., Wallenstein, M. D., Zak, D. R., Zeglin, L. H., Sep. 2008. Stoichiometry of soil enzyme activity at global scale. Ecology Letters.

Sinsabaugh, R. L., Moorhead, D. L., Oct. 1994. Resource allocation to extracellular enzyme production: A model for nitrogen and phosphorus control of litter decomposition. Soil Biology and Biochemistry 26 (10), 1305-1311.

Steenbergh, A. K., Bodelier, P. L. E., Hoogveld, H. L., Slomp, C. P., Laanbroek, H. J., 2011. Phosphatases relieve carbon limitation of microbial activity in Baltic Sea sediments along a redox-gradient. Limnology and Oceanography 56 (6), 2018-2026.

Vance, E. D., Brookes, P. C., Jenkinson, D. S., 1987. An extraction method for measuring soil microbial biomass C. Soil Biology and Biochemistry 19 (6), 703-707.

Wright, A. L., Reddy, K. R., 2001. Phosphorus Loading Effects on Extracellular Enzyme Activity in Everglades Wetland Soils. Soil Science Society of America Journal 65 (2), 588.

Ximenes, E., Kim, Y., Mosier, N., Dien, B., Ladisch, M., Jan. 2011. Deactivation of cellulases by phenols. Enzyme and Microbial Technology 48 (1), 54-60.

Zhang, L.-L., Lin, Y.-M., Zhou, H.-C., Wei, S.-D., Chen, J.H., Jan. 2010. Condensed tannins from mangrove species Kandelia candel and Rhizophora mangle and their antioxidant activity. Molecules (Basel, Switzerland) 15 (1), 420-431. 
Table 1: basic properties as measured at Rhizophora mangle dominated stands on a mangrove-covered island in the Caribbean sea near Belize $(\mathrm{N}=9)$. Numbers after \pm represent standard errors.

\begin{tabular}{lrrc}
\hline Property & dwarf & fringe & Unit \\
\hline tree height & $99 \pm 16$ & $472 \pm 36$ & $\mathrm{~cm}$ \\
tree density & $1.3 \pm .1$ & $1.0 \pm .3$ & individuals m${ }^{-2}$ \\
$\mathrm{pH}$ & $6.7 \pm .1$ & $6.5 \pm .1$ & - \\
temperature & $19.7 \pm .6$ & $16.4 \pm .2$ & ${ }^{\circ} \mathrm{C}$ \\
bulk density & $.92 \pm .1$ & $.92 \pm .1$ & $\mathrm{~g} \mathrm{soil} \mathrm{DW} \mathrm{cm}^{-3}$ \\
\hline
\end{tabular}


Table 2: Measured nutrient and carbon contents in porewater and soil from nitrogen $(\mathrm{N})$ and phosphorus $(\mathrm{P})$ fertilised and unfertilised (C) plots of fringe and dwarf Rhizophora mangle dominated sites on Twin Cays, Belize. Symbols denote significance levels $\left({ }^{* * *} \mathrm{p}<.001,{ }^{* *} \mathrm{p}<.01,{ }^{*} \mathrm{p}<.05, \cdot \mathrm{p}<.1^{*}\right)$ of dwarf/fringe effect under $\mathrm{C}$, and treatment effect under N and P. Significance levels result from either the non-parametric Wilcoxon Rank Sum test (W) for mineral nutrients or Wald's $\chi^{2}$ ANOVA analysis of a mixed effects model with transect as a random factor and $\mathrm{N}$ and $\mathrm{P}$ or Zone as fixed factors for the organic nutrients.

\begin{tabular}{llllllll}
\hline & Dwarf & & \multicolumn{5}{l}{ Fringe } \\
& $\mathbf{C}$ & $\mathbf{N}$ & $\mathbf{P}$ & $\mathbf{C}$ & $\mathbf{N}$ & $\mathbf{P}$ & \\
\hline $\mathrm{NH}_{4}{ }^{+}$ & $0.03^{* *}$ & $0.86^{* * *}$ & 0.02 & $0.01^{* *}$ & 0.06 & n.d. & mmoll \\
$\mathrm{PO}_{4}{ }^{*-}$ & n.d.** & n.d. & $0.30^{* * *}$ & $0.002^{* *}$ & n.d. & $0.05^{* * *}$ & mmoll \\
$\mathrm{NO}_{3}-$ & n.d. & n.d. & n.d. & n.d. & n.d. & n.d. & mmoll \\
$\mathrm{SOC}$ & $336^{* * *}$ & 304. & 335 & $359^{* * *}$ & 379 & 344 & mg Cg soil DW \\
$\mathrm{SON}$ & $14^{*}$ & 13 & 14 & $16^{*}$ & 15 & $12^{*}$ & mg Ng soil DW \\
DOC & $3.3^{* *}$ & 2.8 & 4.2 & $1.9^{* *}$ & 2.8 & 1.8 & mmol Cl \\
DON & n.d. ${ }^{*}$ & n.d. & 0.02 & $0.04^{*}$ & n.d & 0.05 & mmol Nl \\
\hline
\end{tabular}

SOC: soil organic carbon, DOC: dissolved organic carbon, SON: soil organic nitrogen, DON: dissolved organic nitrogen

$$
\text { n.d }=\text { non-detectable }
$$


Table 3: ANOVA-table with Walds $\chi^{2}$ values and significances of N,P and Zone in a mixed effects model of site, soil and microbial properties in fringe and dwarf Rhizophora mangle dominated sites with transect as a random factor. Symbols denote significance levels $\left({ }^{* * *} \mathrm{p}<.001,{ }^{* *} \mathrm{p}<.01,{ }^{*} \mathrm{p}<.05,{ }^{\cdot} \mathrm{p}<.1^{\cdot}\right)$

\begin{tabular}{|c|c|c|c|c|c|c|c|c|c|}
\hline & & \multirow{2}{*}{$\begin{array}{l}\text { tree } \\
\text { height }\end{array}$} & \multirow{2}{*}{\multicolumn{2}{|c|}{ soil elevation $\begin{array}{c}\text { soluble } \\
\text { phenolics }\end{array}$}} & \multirow{2}{*}{$\begin{array}{l}\text { insoluble } \\
\text { phenolics }\end{array}$} & \multicolumn{4}{|c|}{ Microbial } \\
\hline & & & & & & Biomass & $\mathrm{C}: \mathrm{N}$ & $\mathrm{C}: \mathrm{P}$ & $\mathrm{N}: \mathrm{P}$ \\
\hline Zone & & $182.9^{* * *}$ & 8.11 & $42.10^{* * *}$ & 0.77 & $71.86^{* * *}$ & $8.60^{* *}$ & $14.75^{* * *}$ & 0.73 \\
\hline \multirow[t]{2}{*}{ Dwarf } & $\mathbf{N}$ & 0.05 & 0.37 & 1.43 & 0.11 & $7.48^{* *}$ & $8.52^{* *}$ & $5.02 *$ & 1.66 \\
\hline & $\mathbf{P}$ & $25.28^{* * *}$ & $24.89 * * *$ & $34.42^{* * *}$ & $112.4^{* * *}$ & $53.20^{* * *}$ & 3.29 & 1.14 & 0.11 \\
\hline \multirow[t]{2}{*}{ Fringe } & $\mathbf{N}$ & 0.12 & 0.65 & 0.80 & 2.01 & $9.46^{* *}$ & 3.21 & $6.10 *$ & 0.08 \\
\hline & $\mathbf{P}$ & 0.00 & 0.42 & 0.06 & $9.15^{* *}$ & $7.37 * *$ & 3.40 & $12.80 * * *$ & 0.26 \\
\hline
\end{tabular}


Table 4: ANOVA table with Walds $\chi^{2}$ test values of a mixed effects model of the potential enzymatic activity in Rhizophora mangle dominated sites in the dwarf and fringe zone with transect as a random factor and fixed factors printed in boldface. Nutrient effects were separately tested for the dwarf and the fringe zone, the effect of zone was tested on the control treatment only. Symbols denote significance levels $\left({ }^{* * *} \mathrm{p}<.001,{ }^{* *} \mathrm{p}<.01,{ }^{*} \mathrm{p}<.05, \cdot \mathrm{p}<.1\right.$.

\begin{tabular}{lllllllll}
\hline & & BG & CBH & NAG & LAP & GAP & AP & POX \\
\hline Zone & & 1.86 & 1.51 & 1.30 & 2.11 & 2.59 & $7.81^{* *}$ & 3.79 \\
Dwarf & $\mathbf{N}$ & 0.00 & 1.65 & 2.38 & 1.62 & 0.43 & 0.12 & 0.43 \\
& $\mathbf{P}$ & 3.81 & 2.38 & 1.82 & 0.62 & $8.63^{* *}$ & 0.01 & $6.99^{* *}$ \\
Fringe & $\mathbf{N}$ & 3.67 & 0.66 & 0.98 & 0.15 & 0.23 & $10.5^{* *}$ & 0.11 \\
& $\mathbf{P}$ & 0.13 & $4.63^{*}$ & 0.02 & $23.5^{* * *}$ & $8.60^{* *}$ & $5.36^{*}$ & $5.89^{*}$ \\
\hline
\end{tabular}


Table 5: ANOVA table with Walds $\chi^{2}$ test values of a mixed effects model of the potential enzymatic activity in stunted 'dwarf' Rhizophora mangle dominated sites sample location as a random factor, and amendments as fixed factors (N=nitrogen, $\mathrm{P}=$ phosphorus, $\mathrm{C}=$ glucose). Nutrient effects were separately tested incubations with and without $\mathrm{C}$ amendment, the effect of $\mathrm{C}$ amendment was tested on control incubations only. Symbols denote significance levels $\left({ }^{* * *} \mathrm{p}<.001,{ }^{* *} \mathrm{p}<.01,{ }^{*} \mathrm{p}<.05\right.$, $\cdot \mathrm{p}<.1 \cdot)$

\begin{tabular}{llllllll}
\hline & & BG & CBH & NAG & LAP & GAP & AP \\
\hline $\mathbf{C}$ & & $5.17^{*}$ & 0.03 & 1.16 & $7.03^{* *}$ & 3.06 & $5.66^{*}$ \\
$-\mathbf{C}$ & $\mathbf{N}$ & $7.96^{* *}$ & 1.20 & 3.23 & $7.30^{* *}$ & 0.03 & $4.87^{*}$ \\
& $\mathbf{P}$ & $0.01^{* *}$ & 1.15 & $3.66^{*}$ & $7.08^{* *}$ & 0.10 & $0.58^{*}$ \\
& $\mathbf{N}^{*} \mathbf{P}$ & $0.45^{* *}$ & 0.37 & 0.61 & $9.02^{* *}$ & 0.15 & $4.41^{*}$ \\
$+\mathbf{C}$ & $\mathbf{N}$ & $7.27^{* *}$ & 2.38 & $9.19^{* *}$ & $4.59^{*}$ & 0.01 & $19.4^{* * *}$ \\
& $\mathbf{P}$ & $22.2^{* * *}$ & 0.01 & 0.70 & 0.06 & 0.89 & $6.06^{*}$ \\
& $\mathbf{N}^{*} \mathbf{P}$ & $2.11^{* *}$ & 1.57 & 2.59 & $11.2^{* * *}$ & 0.51 & $13.4^{* * *}$ \\
\hline
\end{tabular}




\section{List of Figures}

1 Site characteristics in Rhizophora mangle dominated sites at Twin Cays, Belize. The inner 'dwarf' zone showed stunted growth of Rhizophora trees, while the outer 'fringe' zone showed normal growth. Sites were fertilised with nitrogen (grey bars) or phosphorus (black bars). Relative surface level is defined against the Mean Lower Low Water (MLLW) level. . . . . . . 16

2 Soil microbial characteristics in in Rhizophora mangle dominated sites at Twin Cays, Belize. Two types of Rhizophora mangle dominated sites are distinguished: The inner 'dwarf' zone with stunted growth of Rhizophora mangle trees, and the outer 'fringe' zone where Rhizophora mangle trees have a much taller growth form. Sites in both zones were fertilised with nitrogen (grey bars) or phosphorus (black bars). The horizontal lines indicate average value for marine bacteria as given by Fagerbakke et al. (1996) . . . . . . . . . . . . . . . . . . . . . .

3 Potential activity of oxidative (bars) and hydrolytic microbial exoenzymes (segments) involved in acquiring carbon (light-grey), nitrogen (dark-grey) and phosphorus (black) in soils dominated by Rhizophora mangle with a dwarf (top series) or fringe growth form (middle series). Sites from both zones were subject to long term fertilisation with either nitrogen (N) or phosphorus $(\mathrm{P})$. Hydrolytic enzymes are plotted as circle segments with radius indicating potential activity $(\mathrm{AP}=$ phosphatase, $\mathrm{NAG}=\beta$-N-acetylglucosaminidase, $\mathrm{LAP}=$ leucine aminopeptidase, $\mathrm{GAP}=$ glycine aminopeptidase, $\mathrm{CBH}=$ cellobiohydrolase, $\mathrm{BG}=\beta$-1,4-glucosidase). Potential POX (phenol oxidase) activity is plotted on the bars below the circles. . . . . . . . . .

4 Potential activity of oxidative (bars) and hydrolytic microbial exoenzymes (segments) involved in acquiring carbon (light-grey), nitrogen (dark-grey) and phosphorus (black) in soils dominated by stunted 'dwarf' Rhizophora mangle after four days of incubation with amendment of various combinations of ammonium $(\mathrm{N})$, phosphate $(\mathrm{P})$ and glucose $(\mathrm{C})$. Hydrolytic exoenzymes are plotted as circle segments with radius indicating potential activity $(\mathrm{AP}=$ phosphatase, $\mathrm{NAG}=\beta$-N-acetylglucosaminidase, $\mathrm{LAP}=$ leucine aminopeptidase, $\mathrm{GAP}=$ glycine aminopeptidase, $\mathrm{CBH}=$ cellobiohydrolase, $\mathrm{BG}=\beta$-1,4-glucosidase) $\ldots \ldots \ldots \ldots \ldots$ 

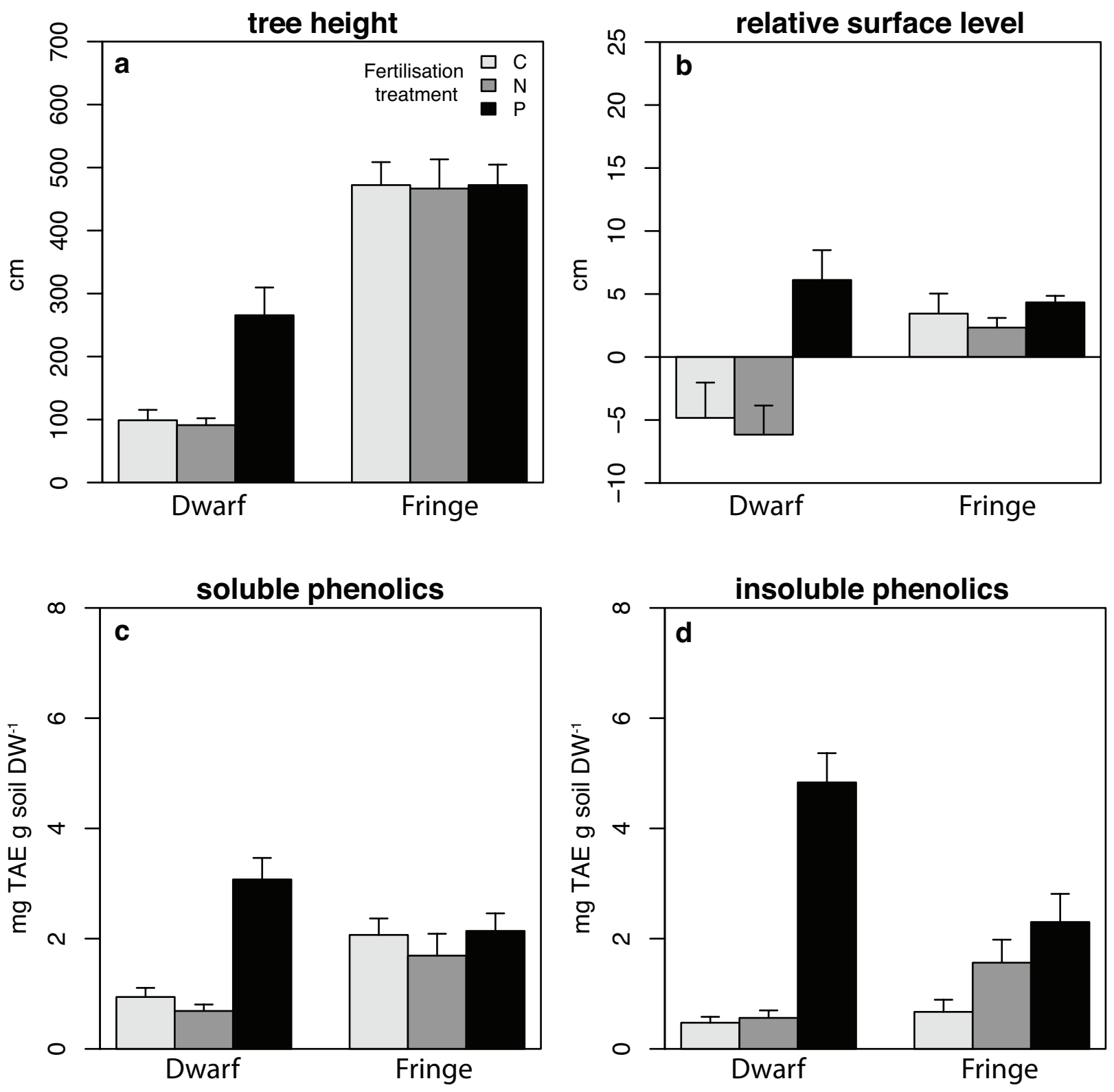

Figure 1: Site characteristics in Rhizophora mangle dominated sites at Twin Cays, Belize. The inner 'dwarf' zone showed stunted growth of Rhizophora trees, while the outer 'fringe' zone showed normal growth. Sites were fertilised with nitrogen (grey bars) or phosphorus (black bars). Relative surface level is defined against the Mean Lower Low Water (MLLW) level. 

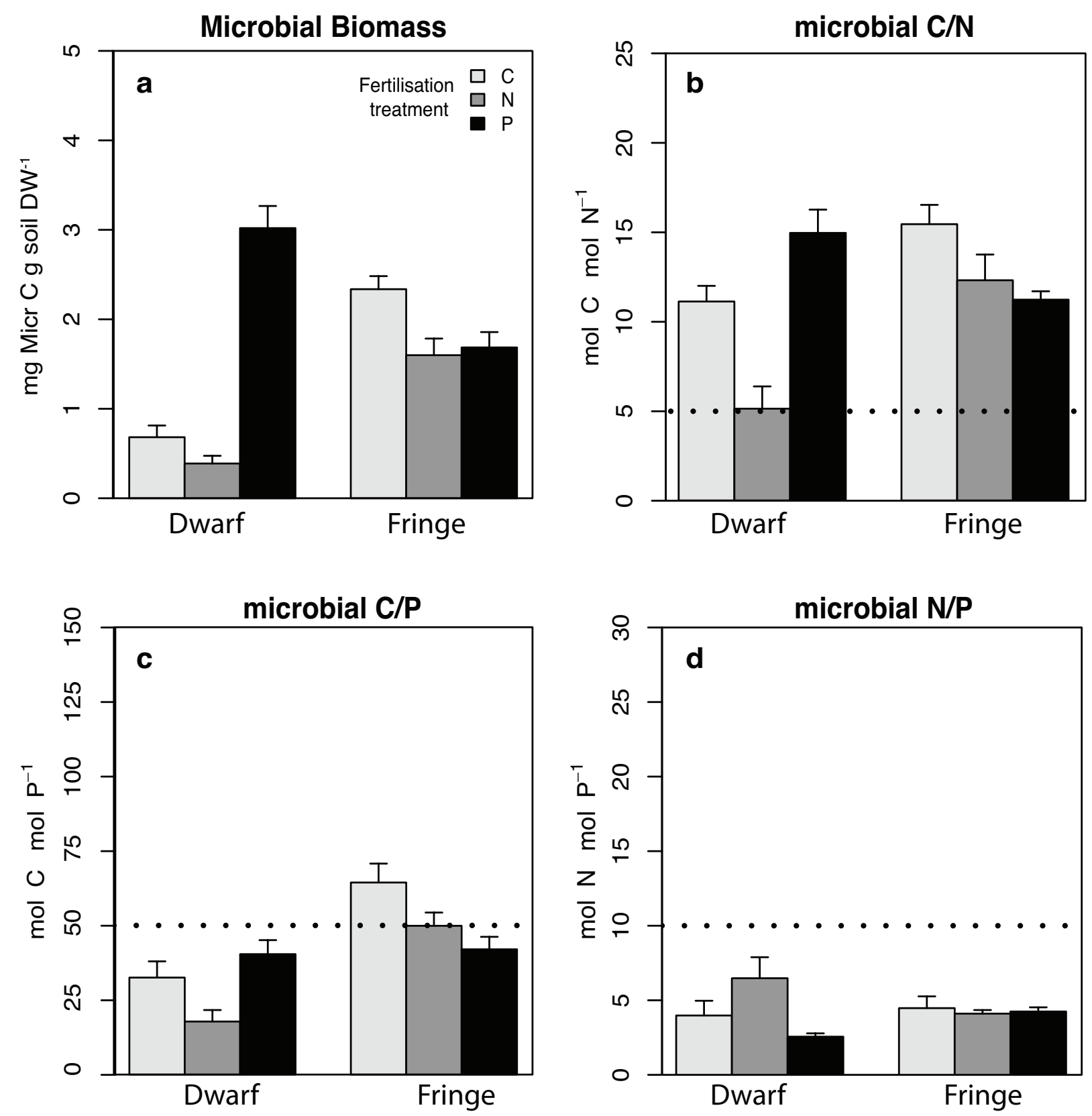

Figure 2: Soil microbial characteristics in in Rhizophora mangle dominated sites at Twin Cays, Belize. Two types of Rhizophora mangle dominated sites are distinguished: The inner 'dwarf' zone with stunted growth of Rhizophora mangle trees, and the outer 'fringe' zone where Rhizophora mangle trees have a much taller growth form. Sites in both zones were fertilised with nitrogen (grey bars) or phosphorus (black bars). The horizontal lines indicate average value for marine bacteria as given by Fagerbakke et al. (1996) 

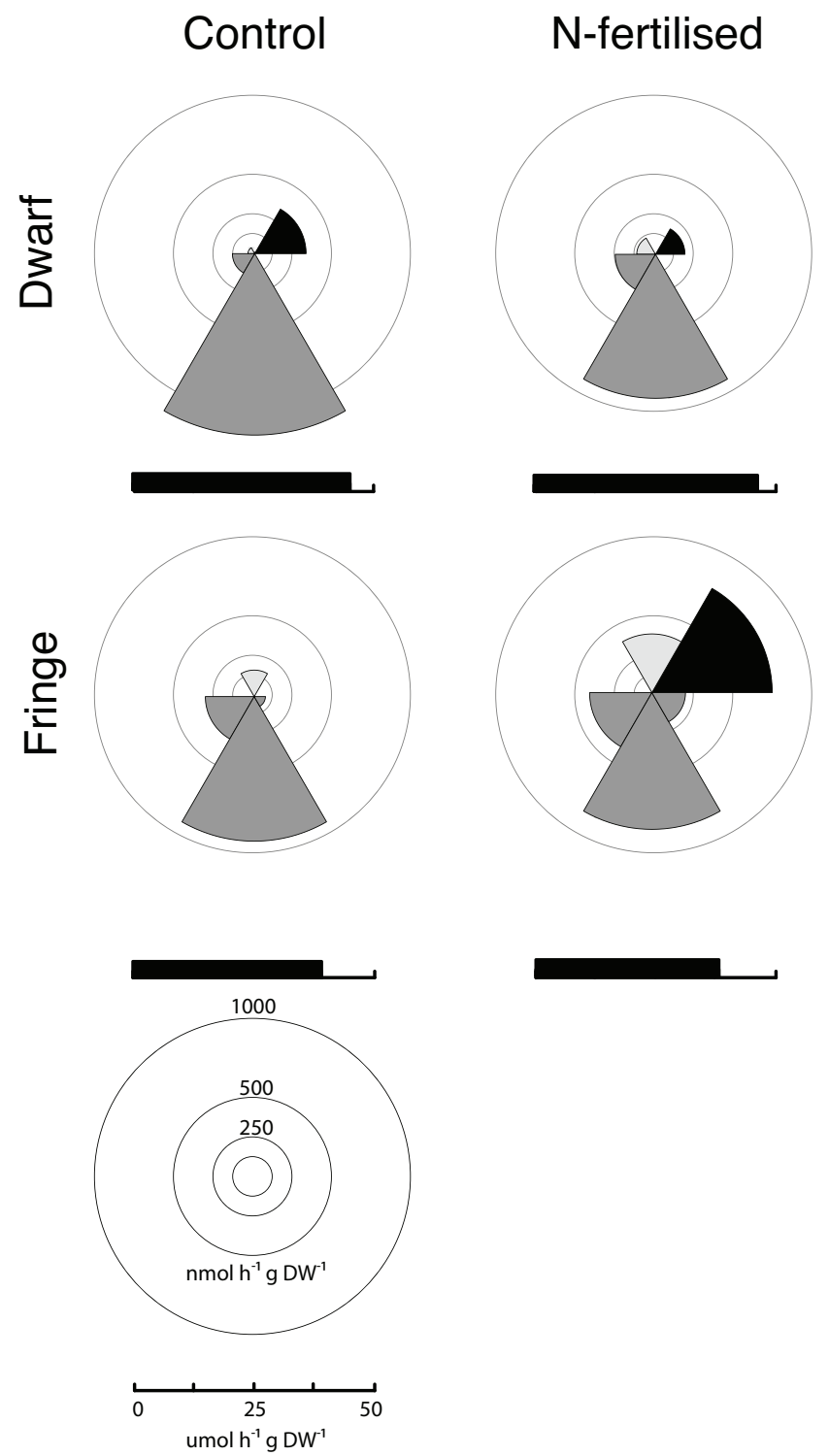

P-fertilised
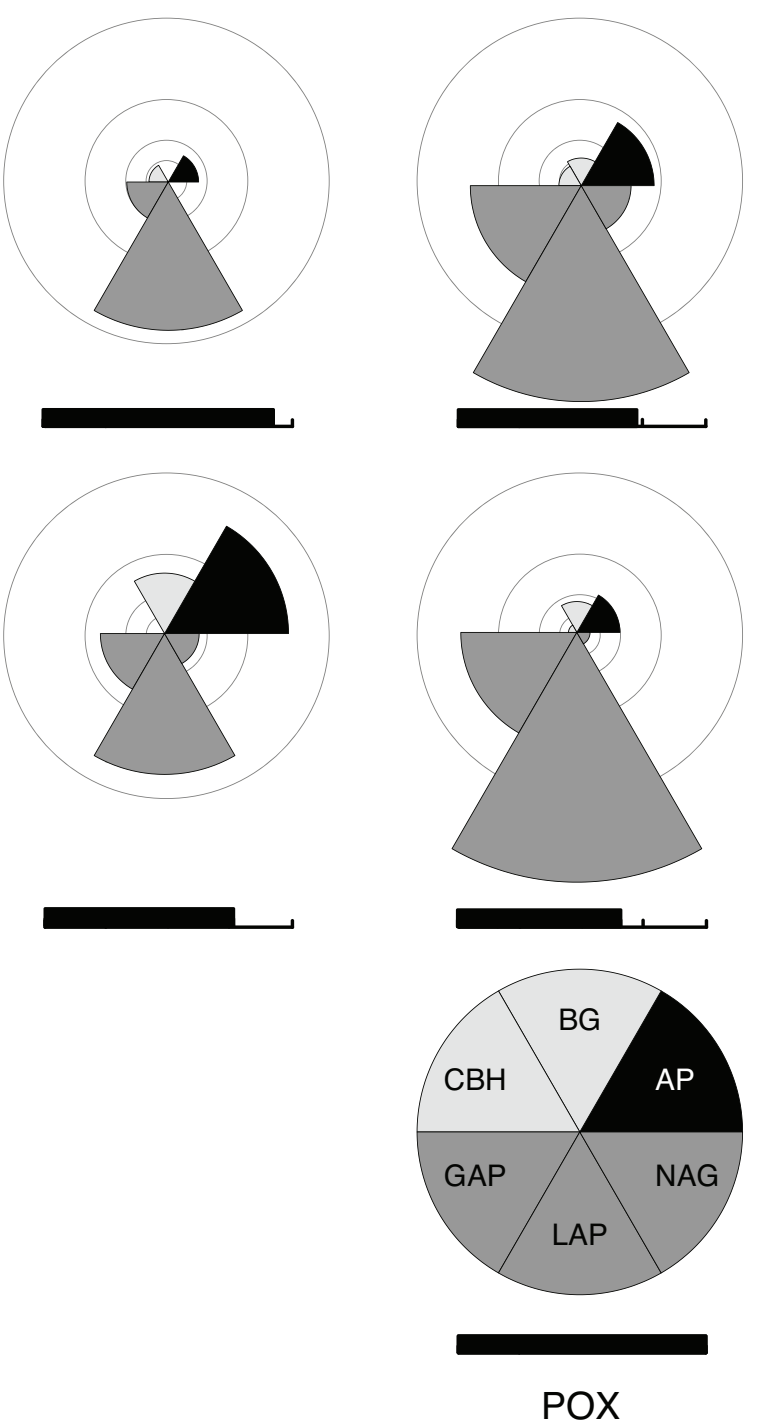

Figure 3: Potential activity of oxidative (bars) and hydrolytic microbial exoenzymes (segments) involved in acquiring carbon (light-grey), nitrogen (dark-grey) and phosphorus (black) in soils dominated by Rhizophora mangle with a dwarf (top series) or fringe growth form (middle series). Sites from both zones were subject to long term fertilisation with either nitrogen $(\mathrm{N})$ or phosphorus (P). Hydrolytic enzymes are plotted as circle segments with radius indicating potential activity (AP= phosphatase, $\mathrm{NAG}=\beta$-N-acetylglucosaminidase, $\mathrm{LAP}=$ leucine aminopeptidase, $\mathrm{GAP}=$ glycine aminopeptidase, $\mathrm{CBH}=$ cellobiohydrolase, $\mathrm{BG}=\beta-1,4$-glucosidase). Potential POX (phenol oxidase) activity is plotted on the bars below the circles. 

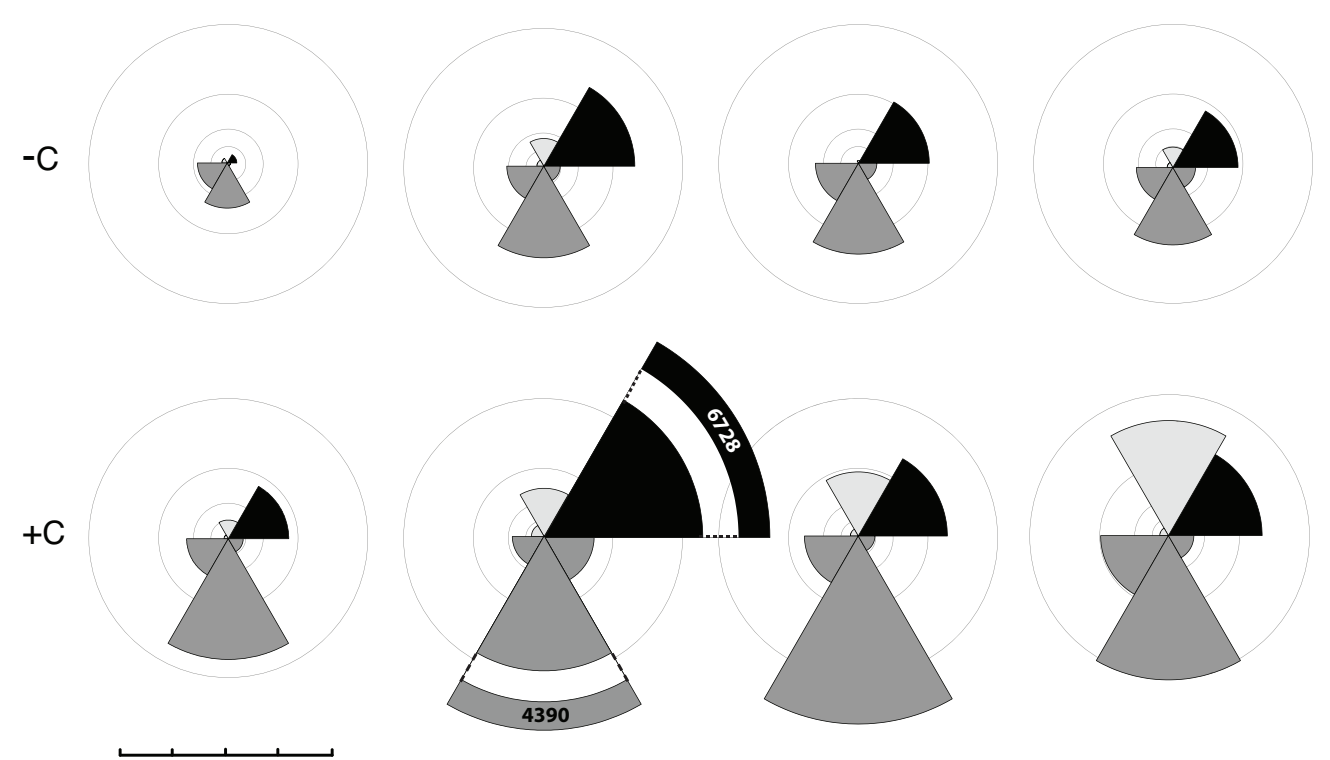

Control

$\mathrm{N}$

$P$

NP
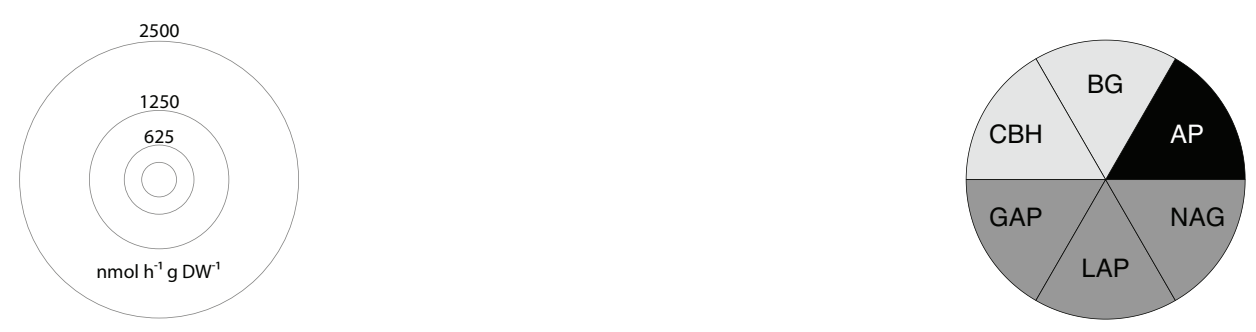

Figure 4: Potential activity of oxidative (bars) and hydrolytic microbial exoenzymes (segments) involved in acquiring carbon (light-grey), nitrogen (dark-grey) and phosphorus (black) in soils dominated by stunted 'dwarf' Rhizophora mangle after four days of incubation with amendment of various combinations of ammonium (N), phosphate $(\mathrm{P})$ and glucose $(\mathrm{C})$. Hydrolytic exoenzymes are plotted as circle segments with radius indicating potential activity $(\mathrm{AP}=$ phosphatase, $\mathrm{NAG}=\beta-\mathrm{N}-$ acetylglucosaminidase, $\mathrm{LAP}=$ leucine aminopeptidase, $\mathrm{GAP}=$ glycine aminopeptidase, $\mathrm{CBH}=$ cellobiohydrolase, $\mathrm{BG}=\beta-1,4-$ glucosidase). 